\title{
Antibiotic (Gentamicin) Impact on Bacterial Flacherrie Disease of Silkworm,
} Bombyx mori L..

\author{
Souad M. Mahmoud, Rehab H. Taha and Saad, I. A. I. \\ Sericulture Department, Plant Protection Research Institute, Agricultural Research \\ Center, Egypt
}

\section{ABSTRACT}

There are many factors that influence the success of silk production. Bacterial flacherrie considered the most important factor. Antibiotics showed promising results for controlling of silkworm diseases and to improve the production of silk and harvesting superior crop. The effect of antibiotic (Gentamicin) upon the infection with bacterial flacherrie was discussed. Gentamicin as a cheap antibiotic in Egypt can be used easily by trainees and farmers. It was found that Gentamicin significantly increases the effective rate of rearing (ERR \%) and larval weight $(97.333 \%$ and $2.631 \mathrm{gm}$, respectively). Single female and male cocoon weights (1.400 gm and 1.068 gm, respectively) and male cocoon shell ratio (22.708\%) were significantly increased under the effect of antibiotic treatment comparing with control. Polymorphism among the tested haemolymphal samples were investigated using SDS-PAGE electrophoresis. A variation was detected in the protein banding pattern with considerable polymorphism (88.2\%), with the appearance of 2 monomorphic bands, 12 polymorphic and 3 unique bands.

Keywords : Antibiotic - Bacterial Flacherrie Disease - Bombyx mori

\section{INTRODUCTION}

Bombyx mori L. has an economic importance because of the commercial value of its silk. Therefore several trials for developing the biological processes and improving the qualitative and quantitative characters of silk yield took place (Taha, 2002).

Bacterial flacherrie is a common disease of mulberry silkworm. The aetiology of bacterial diseases is not fully understood because of the multiplicity of bacterial types involved in bacterial infections (Choudhury et al., 2002). Generalized symptoms of insects associated with bacterial infections are loss of appetite, diarrhea (discharge of watery feces), and vomiting then the larvae softening and die emitting a foul odor (Tanada and Kaya, 1993). Since there are no specific preventive measures for the occurrence and spread of disease other than sanitized rearing methods, the only commercial practice today is to discard large stocks of worms in case of infection to avoid the spread of disease (Acharya et al., 2002). Several prophylactic and curative measures are aimed for managing the disease taking into account the ecofriendly nature and cost effectiveness. Antibiotics are widely used in sericulture industry as a component of bed disinfectants and as therapeutic applications against bacterial diseases (Subramanian et al., 2009).

In sericulture the productivity and quality largely depends on the healthiness, growth of the silkworm larvae and the suitable environmental conditions. Growth and development of larvae depends on the physiological processes that take place in the silkworm. Therefore, improvement of silk quality means improvement of the feed nutrition and upkeep of the larval health, since silkworm is highly susceptible to infection caused by major pathogenic groups. Broad spectrum antibiotics viz., 
penicillin, streptomycin, tetracycline and chloramphenicol were already tried on silkworm and found successful (Venkatesh and Srivastava, 2010). Antibiotics in silkworm are approved for four different purposes: disease treatment, disease prevention, disease control and for health maintenance or growth promotion (Phillips et al., 2004).

Haemolymph has a key role in innate immunity response, which is triggered when bacteria enter the silkworm body (Hou et al., 2010). Insects possess an effective innate immune system against foreign microorganisms. Innate immunity of insects is divided into two major reaction types: humoral and cellular reactions. Humoral reactions involve soluble proteins in the hemolymph such as phenoloxidase, antimicrobial proteins (AMPs), lysozymes, and lectins, whereas hemocytes mediate cellular reactions such as phagocytosis, encapsulation and nodule formation. In Bombyx mori, six different families of AMPs have been identified: Cecropin, Attacin, Lebocin, Moricin, Gloverin, and Defensin. One lysozyme and three lysozyme-like proteins, one of which is involved in elimination of invading pathogens, are also found in the silkworm (Tanaka and Yamakawa, 2011).

The present study is a trail for enhancing larval resistance against bacterial infection which is caused by several bacterial types by using a commercial antibiotic (Gentamicin) and its effect on biological and biochemical characters.

\section{MATERIAL AND METHODS}

Silkworm eggs of univoltine race, was obtained from the Sericulture Research Department (SRD) of Plant Protection Research Institute (PPRI).

\section{Isolation of bacteria}

Bacterial pathogens were collected from diseased black thorax Septicemia infected larvae, the diseased larvae were crushed by using mortar and pestle and the solution was filtered. The filtrate was centrifuged at $4000-5000 \mathrm{rpm}$ for 10 minutes. The supernatant was discarded and the pellet was used for bacterial culture after resuspending in distilled water (Aneja, 2003).

\section{Preparation of Luria Agar (LA) medium and bacterial culture}

After culture preparation, the bacterial sample was streaked in LA under aseptic conditions in a laminar air flow chamber with the help of streaking loop then incubated at $37^{\circ} \mathrm{C}$ overnight. After $24 \mathrm{hr}$ the bacterial growth was noticed, and further it was sub cultured. A sample of bacteria was taken with the help of a loop and centrifuged for 15 minutes at $4000 \mathrm{rpm}$. By discarding the supernatant, pellet sedimented at the bottom of the tube was dissolved in distilled water. The presence of bacteria was confirmed by staining with basic dyes like crystal violet and methylene blue. (Suparna et al., 2011).

\section{Infecting silkworm larvae with bacteria}

The rearing technique was done in the lab at $28 \pm 1{ }^{\circ} \mathrm{C}$ and $75 \pm 5 \% \mathrm{RH}$, following the standard methodology of rearing according to (Krishnaswamy, 1978).

Larvae were fed on leaves of Kokuzo-27 mulberry variety. After the second moult, larvae were separated into three groups; control group, infected group and treated group with 50 larvae/ replica for each group.

Silkworms were infected with the bacteria by smearing the bacterial solution onto the leaf surface and dried in shade then fed to larvae. The second group were fed with distilled water smeared mulberry leaves and considered as a control. For the diseased and treated groups, the infected leaves were provided during the first feed on first day and thereafter the larvae were fed with normal leaves. On the next day, the fresh leaves dipped in Gentamicin $(40 \mathrm{mg} / 1000 \mathrm{ml}$ distal water) were fed to the 
treated group only. The control and diseased groups were fed on normal leaves. Treatments were administered twice, once on the second day of the third instar and the other on the first day of the fourth instar (Manimegalai et al., 2010).

Observations were made for each group and each replicate on larval duration, effective rate of rearing (ERR), larval weight, male and female cocoon weight, shell weight and shell ratio. Data were recorded and subjected to analysis of variance according to Snedecor and Cochran (1981).

At the sixth day of the fifth larval instar haemolymphal samples were collected from control group (healthy and naturally diseased larvae), infected group (healthy and diseased larvae) and treated group (healthy and diseased larvae); lanes 1, 2,3,4,5 and 6 respectively and stored in eppendrof tube.

\section{Preparation of protein sample}

10 microlitres of haemolymph sample was taken in an eppendrof tube which was collected from each group. 100 microlitres of Tris buffer ( $\mathrm{pH}$ 6.8) was taken and mixed with haemolymph sample to dilute the sample, and from that 15 microlitres was taken in another eppendrof tube equal volume of sample buffer was also added.

The sample in the eppendrof tube was thoroughly mixed with the help of vertex. The sample solution was heated in boiling water for 2-3 $\mathrm{min}$ to ensure complete interaction between proteins and SDS, and a pinch of Bromophenol blue is used as a tracking dye.

\section{Electrophoresis}

Electrophoresis of sample solution was carried out in $12 \%$ separating gel. The gel run at $150 \mathrm{~V}$ for 10-20 min until the tracking dye moved till the end of the gel. After run was completed the gel was removed and is stained with Coomassie Brilliant Blue for 45 min-1hr. Standard molecular weight markers were used for estimating the molecular weight (Laemmli, 1970).

\section{RESULTS AND DISCUSSION}

\section{Bioassay:}

The mean values of the most important economical characters are given in Table (1). Larval duration showed significant increase in infected group (1008, 888 and 816 hrs, respectively).

The highest effective rate of rearing (ERR \%) and mature larval weight (gm) were recorded for the treated group ( $97.333 \%$ and $2.631 \mathrm{gm}$, respectively).

Single female and male cocoon weights (1.400 and $1.068 \mathrm{gm}$, respectively) and male cocoon shell ratio $(22.708 \%)$ were significantly increased under the effect of antibiotic treatment comparing with control.

Table 1: The mean values of the most important economical silkworm characters.

\begin{tabular}{|c|c|c|c|c|}
\hline Parameters & Control & infected & Treated & LSD \\
\hline Larval Duration (hr) & $888 \mathrm{~b}$ & $1008 \mathrm{a}$ & $816 \mathrm{c}$ & 21.823 \\
\hline ERR \% & $95.333 \mathrm{ab}$ & $78.667 \mathrm{~b}$ & $97.333 \mathrm{a}$ & 17.823 \\
\hline Larval Weight (gm) & $2.331 \mathrm{~b}$ & $2.114 \mathrm{c}$ & $2.631 \mathrm{a}$ & 0.188 \\
\hline Cocoon weight (gm) & $1.266 \mathrm{~b}$ & $1.239 \mathrm{~b}$ & $1.400 \mathrm{a}$ & 0.124 \\
\hline Cocoon Shell weight (gm) & $0.230 \mathrm{a}$ & $0.205 \mathrm{a}$ & $0.252 \mathrm{a}$ & 0.054 \\
\hline Cocoon Shell \% & $18.238 \mathrm{a}$ & $16.782 \mathrm{a}$ & $18.013 \mathrm{a}$ & 3.833 \\
\hline Cocoon Weight (gm) & $1.037 \mathrm{~b}$ & $1.052 \mathrm{~b}$ & $1.068 \mathrm{a}$ & 0.030 \\
\hline Cocoon Shell Weight (gm) & $0.204 \mathrm{a}$ & $0.211 \mathrm{a}$ & $0.232 \mathrm{a}$ & 0.054 \\
\hline Cocoon Shell \% & $20.507 \mathrm{~b}$ & $20.622 \mathrm{~b}$ & $22.708 \mathrm{a}$ & 1.211 \\
\hline
\end{tabular}

In a row, means followed by same letter (s) are not significantly different at 0.01 by LSD 
From the obtained results it may be concluded that, Gentamicin increases insect resistance/tolerance and ERR. Also, it improves larval growth which reflects on cocoon weight and silk ratio increment.

The growth- rates of animals have been observed to increase through the feeding of low concentrations of antibiotics. Beneficial effects of antibiotics by modulation of gut micro-flora and influence on mucosal immunity or through altering enzymatic activities has been extensively studied in humans, animals and many insects (Yeung et al., 2002 ). While in many cases administration of antibiotics was reported to have detrimental effect on intestinal microflora of silkworms which cause adverse effects on the physiological system (Subramanian et al., 2009). So, in the present study it is recommended to apply low concentration of antibiotics. As the antibiotic feed supplementation not only showed prophylactic measures to prevent bacterial infections but also enhanced the feeding nutrition and economical parameters in Bombyx mori as suggested by (Sheebha et al., 2008).

The development and economic production of sericulture largely and greatly depends on the metabolic modulations and molecular mechanism of silkworm, besides its genetic composition and immunological resistance (Babu et al., 2005).

Hamamoto et al., (2005) reported that, antibiotics used for clinical purposes may have therapeutic effects on silkworms infected with the pathogens Staphylococcus aureus and Candida albicans. Kaito et al., (2002) found that when ampicillin $(200 \mu \mathrm{g})$, oxacillin $(200 \mu \mathrm{g})$ or vancomycin $(200 \mu \mathrm{g})$ was injected in the silkworm larvae after injection of the bacterium, at least $90 \%$ of the larvae survived for 4 days.

\section{Electrophoresis}

Fig. (1) demonstrated the SDS-protein profile of the haemolymphal samples of healthy and flacherrie diseased larvae of the investigated groups.

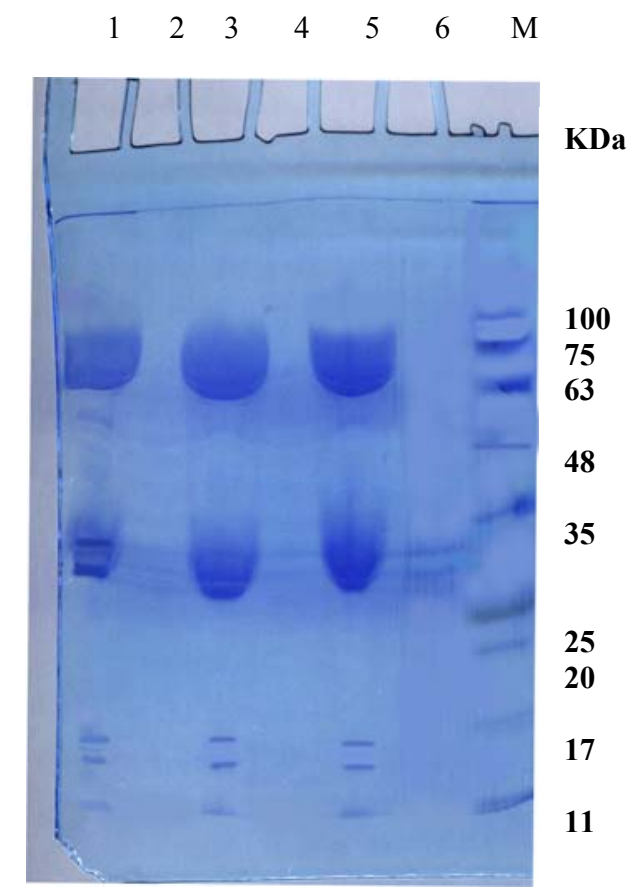

Fig. 1: The electrophoretic pattern of the haemolymph demonstrated the SDS- protein profiles of control, infected and treated samples.

M: molecular weights of marker (KDa)

Lane 1: Healthy sample from control group

Lane 3: Healthy sample from infected group

Lane 5: Healthy sample from treated group

Lane 2 : Flacherrie diseased sample from control group

Lane 4: Flacherrie diseased sample from infected group

Lane 6: Flacherrie diseased sample from treated group 
Tables (2 and 3 ) revealed the computer analysis of protein bands and showed the presence $(+)$ or absence $(-)$ of bands. The electrophoretic pattern of healthy haemolymphal samples from control, infected and treated groups showed a total of 14 protein bands with molecular weights $(68.31,65.08,54.50,52.06,49.08,45.03$, $42.33,41.43,31.83,29.76,27.76,14.25,12.86$ and10.57 KDa, respectively). Whereas, in the flacherrie diseased sample of control group, a total of 8 protein bands were observed with molecular weights $(68.31,65.08,54.50,52.06,45.03,31.83,29.76$ and $28.98 \mathrm{KDa}$, respectively). The flacherrie diseased sample of infected group showed 7 protein bands with molecular weights $(68.31,65.08,54.50,52.06,45.03,31.83$ and 29.76 KDa, respectively). Finally, the flacherrie diseased sample of treated group showed 5 protein bands with molecular weights $(37.01,36.12,31.83,29.76,27.76$ $\mathrm{KDa}$, respectively).

Table 2: The molecular weight of the different protein bands

\begin{tabular}{|c|c|c|c|c|c|c|c|}
\hline MW & Lane 1 & Lane 2 & Lane 3 & Lane 4 & Lane 5 & Lane 6 & Marker \\
\hline Band 1 & 68.31 & 68.31 & 68.31 & 68.31 & 68.31 & 37.01 & 87.75 \\
\hline Band 2 & 65.08 & 65.08 & 65.08 & 65.08 & 65.08 & 36.12 & 77.66 \\
\hline Band 3 & 54.50 & 54.50 & 54.50 & 54.50 & 54.50 & 31.83 & 65.45 \\
\hline Band 4 & 52.06 & 52.06 & 52.06 & 52.06 & 52.06 & 29.76 & 50.02 \\
\hline Band 5 & 49.08 & 45.03 & 49.08 & 45.03 & 49.08 & 27.76 & 37.31 \\
\hline Band 6 & 45.03 & 31.83 & 45.03 & 31.83 & 45.03 & - & 24.42 \\
\hline Band 7 & 42.33 & 29.76 & 42.33 & 29.76 & 42.33 & - & 21.26 \\
\hline Band 8 & 41.43 & 28.98 & 41.43 & - & 41.43 & - & 15.73 \\
\hline Band 9 & 31.83 & - & 31.83 & - & 31.83 & - & 10.90 \\
\hline Band 10 & 29.76 & - & 29.76 & - & 29.76 & - & - \\
\hline Band 11 & 27.76 & - & 27.76 & - & 27.76 & - & - \\
\hline Band 12 & 14.25 & - & 14.25 & - & 14.25 & & - \\
\hline Band 13 & 12.86 & - & 12.86 & - & 12.86 & & - \\
\hline Band 14 & 10.57 & - & 10.57 & - & 10.57 & & - \\
\hline
\end{tabular}

Table 3: The presence (+), absence (-) of bands and type of bands in all tested haemolymphal samples

\begin{tabular}{|c|c|c|c|c|c|c|c|}
\hline MW & Lane 1 & Lane 2 & Lane 3 & Lane 4 & Lane 5 & Lane 6 & Polymorphism \\
\hline 68.31 & + & + & + & + & + & - & polymorphic \\
\hline 65.08 & + & + & + & + & + & - & polymorphic \\
\hline 54.50 & + & + & + & + & + & - & polymorphic \\
\hline 52.06 & + & + & + & + & + & - & polymorphic \\
\hline 49.08 & + & - & + & - & + & - & polymorphic \\
\hline 45.03 & + & + & + & + & + & - & polymorphic \\
\hline 42.33 & + & - & + & - & + & - & polymorphic \\
\hline 41.43 & + & - & + & - & + & - & polymorphic \\
\hline 37.01 & - & - & - & - & - & + & unique \\
\hline 36.12 & - & - & - & - & - & + & unique \\
\hline 31.83 & + & + & + & + & + & + & monomorphic \\
\hline 29.76 & + & + & + & + & + & + & monomorphic \\
\hline 28.98 & - & + & - & - & - & - & unique \\
\hline 27.76 & + & - & + & - & + & + & polymorphic \\
\hline 14.25 & + & - & + & - & + & - & polymorphic \\
\hline 12.86 & + & - & + & - & + & - & polymorphic \\
\hline 10.57 & + & - & + & - & + & - & polymorphic \\
\hline
\end{tabular}

M: molecular weights of marker (KDa)

Lane 1: Healthy sample from control group

Lane 3: Healthy sample from infected group

Lane 2: Flacherrie diseased sample from control group

Lane 4: Flacherrie diseased sample from infected group

Lane 5: Healthy sample from treated group

Lane 6: Flacherrie diseased sample from treated group

17 bands were recorded in the all tested haemolymphal samples with polymorphism of $88.23 \%$. 2 monomorphic bands were recognized, while the remaining 12 bands were considered as polymorphic ones. 3 bands were recognized as unique bands, as shown in Table (3). The detected polymorphism in the resulted protein profiles could be attributed to some environmental stresses (Sammour et al., 
1993) or resulted from the mutational events that alter the performance of their encoding genes as suggested by (Rottenberg et al., 2000). The recorded polymorphism percentage in this study could support this issue.

Unique bands were appeared in the bacterial flacherrie diseased samples for both control and treated groups only. Two unique protein bands with 37.01 and 36.12 $\mathrm{KDa}$ were appeared in flacherrie diseased sample of treated group and one unique protein bands with $28.98 \mathrm{KDa}$ in flacherrie diseased sample of control group. The appearance of unique bands in diseased samples may be related to immune proteins.

Bacterial infection can be used to survey the host silkworm genome-wide responses, including its innate immune response to the pathogen at transcriptional level and to provide another detailed comprehension of the interaction between the pathogen and its host. A lot of basal metabolic pathways were significantly modulated. Genes related to poisoning that might be a key to silkworm septicemia, are also regulated (Huang et al., 2009). In response to microbial infection, antimicrobial proteins (AMPs) and lysozymes are rapidly produced primarily in the fat body (FB), and subsequently secreted into the haemolymph to eliminate invading pathogens. In Bombyx mori, six different families of (AMPs) have been identified: Cecropin, Attacin, Lebocin, Moricin, Gloverin, and Defensin were up-regulated at 24 hours post the infection (Tanaka and Yamakawa, 2011).

In the present study, there is a common band in all tested samples with molecular weight $29.76 \approx 30 \mathrm{KDa}$. This protein type is known as haemolymph protein or larval serum protein (BmLSP) according to Fujiwara and Yamashita (1992), with 262 amino acid residues. Izumi et al., (1981) stated that, a group of structurally related proteins called $30 \mathrm{~K}$ proteins, because of their approximate molecular weights of $30 \mathrm{KDa}$, were found to be stored in the larval haemolymph of silkworms in a stagedependent fashion. The $30 \mathrm{~K}$ proteins are minimally detectable in the haemolymph before day 3 of the fifth larval instar, but become major haemolymph proteins in the early pupal stage because of progressive increase in expression after the 3rd day of fifth instar larvae. Kim et al., (2003) identified the $30 \mathrm{kDa}$ protein as an anti-apoptotic component and inhibit a poptosis in silkworm larvae. It inhibited the virus or chemical-induced apoptosis in human cells as well as insect cells. They recommend that, the recombinant $30 \mathrm{~K}$ protein can be effectively used to minimize cell death and consequently increase the productivity by extending the production time of host cells in commercial animal cell culture.

Naletova et al., (1982) identified the protein with $69 \mathrm{KDa}$ as carboxylesterase, which has antigenic activity. In this study, 68.3 KDa protein present in all tested samples except the flacherrie diseased sample from treated group.

Protein with $49.08 \mathrm{KDa}$ may be the paralytic peptide binding protein according to Nakahara et al., (2009) with 421 amino acid residue. This plays an important role in silkworm immunity (Tanaka and Yamakawa, 2011).

Antibiotics used clinically in humans also have therapeutic effects against silkworms injected with Staphylococcus aureus and Pseudomonas aeruginosa (Kaito et al., 2002). Hossain et al., (2006) estimated the bacterial exotoxins that kill silkworms. The 50\% lethal dose (LD50) of staphylococcal alpha-toxin is $12 \mu \mathrm{g} / \mathrm{g}$; and that of staphylococcal beta-toxin is $9 \mu \mathrm{g} / \mathrm{g}$; that of Pseudomonas exotoxin A is 0.14 $\mu \mathrm{g} / \mathrm{g}$; that of diphtheria toxin is $1.1 \mu \mathrm{g} / \mathrm{g}$.

Most of the LD50 values obtained in silkworm were similar to the reported values in mice, suggesting that silkworms can be used as a model to study the general effects of bacterial exotoxins on multicellular organisms, including humans. In agreement with the opinion of Yamakawa and Tanaka (1999), it is expected that the 
study of B. mori immunity can contribute in the near future to the medical field developing new antibiotics based on bacterial proteins and to the agricultural field establishing transgenic plants having antimicrobial protein genes.

\section{CONCLUSION}

Antibiotics improve feed consumption and growth by stimulating metabolic processes within the silkworm as well as reduce the occurrence of diseases which causes immense loss to sericulture industry. Antibiotics that are used in clinic to treat infection in mammals showed therapeutic effect in silkworm larvae infected with bacteria. The silkworm larval infection system may provide a convenient and novel way to discover new antibiotics which have not been found using the existing systems of drug screening and pathogen studies.

\section{REFERENCES}

Aneja, K. R. (2003): Experiments in microbiology, Plant pathology and biotechnology. New Age International (P) Limited Publeshers, 4th Edition. P.376

Acharya, A.; S. Sriram; S. Sehrawat; M. Rahman; D. Sehgal and K. P. Gopinathan (2002): Bombyx mori nucleopolyhedrovirus: Molecular biology and biotechnological applications for large-scale synthesis of recombinant proteins. Curr. Sci. 28: 455-465.

Babu, M. S.; G. Gopalaswamy and N. Chandramohan (2005): Identification of an antiviral principle in Spirulina platensis against Bombyx mori nuclear polyhedrosis virus (bmnpv). Indian J of Biotechnology, 4: 384-388.

Choudhury, A.; A. Guha; A. Yadav; B. Unni and M. Roy (2002): Causal organism of flacherie in the silkworm Antheraea assama Ww: isolation, characterization and its inhibition by garlic extract. Phytother. Res., 16: S89-S90 .

Naletova, E. A.; T. A. Egorova and I. B. Filippovich (1982): Isolation and properties of carboxylesterase from haemolymph of the silkworm Bombyx mori L. Biokhimiia Moscow Russia, 47 (11): 1844 -1851.

Kim, E. J.; H. J. Park and T. H. Park (2003): Inhibition of apoptosis by recombinant $30 \mathrm{~K}$ protein originating from silkworm haemolymph. Biochemical and Biophysical Research Communications, 308 (3):523-528.

Fujiwara,Y. and O. Yamashita (1992): Gene structure of Bombyx mori larval serum protein (BmLSP). Insect Mol. Biol., 1 (2): 63-69.

Lammli, U. K. (1970): Cleavage of structural proteins during the assembly of the head of bacteriophage T4. Nature, 227: 680 -685.

Tanaka, H. and M. Yamakawa (2011): Regulation of the innate immune responses in the silkworm, Bombyx mori. ISJ, 8: 59-69.

Hamamoto, H.; K. Kurokawa; C. Kaito; K. Kamura; R. I. Manitra; H. Kusuhara; T. Santa and K. Sekimizu (2005): Quantitative evaluation of the therapeutic effects of antibiotics using silkworm as an animal model. Res. Adv. in Antimicrob. Agents \& Chemother., 5: 1-23.

Hossain, M. S.; H. Hamamoto; Y. Matsumoto; I. M. Razanajatovo; J. Larranaga; C. Kaito; H. Kasuga and K. Sekimizu (2006): Use of silkworm larvae to study pathogenic bacterial toxins. J Biochem. (Tokyo), 140: 439-444. 
Huang, L.; T. Cheng; P. Xu; D. Cheng; T. Fang and Q. Xia (2009): A Genome wide survey for host response of silkworm, Bombyx mori during pathogen Bacillus bombyseptieus infection. PLoS One, 4(12): e8098, www.plosone.org.

Izumi, S.; A. Fujie; S. Yamada and S. Tomino (1981): Molecular properties and biosynthesis of major plasma proteins in Bombyx mori. Biochim Biophys Acta, 670: 222-229.

Kaito, C.; N. Akimitsu; H. Watanabe and K. Sekimizu (2002): Silkworm larvae as an animal model of bacterial infection pathogenic to humans. Microbial Pathogenesis, 32(4): 183-190.

Krishnaswamy, S. (1978): New technology of silkworm rearing. Central Sericultural Research and Training Institute, Central Silk Board, India, Bulletin (2):1-23.

Manimegalai, S.; T. Rajeswari; R. Shanmugam and G. Rajalakshmi (2010): Botanicals against nuclear polyhedrosis virus infecting three breeds of mulberry silkworm, Bombyx mori L. J of Biopesticides 3(1): $242-245$.

Nakahara,Y.; S. Shimura; C. Ueno; Y. Kanamori; K. Mita; M. Kiuchi and M. Kamimura (2009): Purification and characterization of silkworm hemocytes by flow cytometry. Dev. Comp. Immunol., 33 (4): 439-448.

Phillips, I.; M. Casewell; T. Cox; B. Groot; C. Friis; R. Jones; C. Nightingale; R. Preston and J. Waddell (2004): Does the use of antibiotics in food animals pose a risk to human health? A critical review of published data. J. of Antimicrobial Chemotherapy, 54(1): 76-278.

Rottenberg, A.; E. Nevo and D. Zohary (2000): Genetic variability in sexually monomorphic and dimorphic populations of Populus euphratica (Salicaceae). Can. J. Forest. Res., 30: 482-486.

Subramanian, S.; P. Mohanraj and M. Muthuswamy (2009): New paradigm in silkworm disease management using probiotic application of Streptomyces noursei. Karnataka J. Agric. Sci., 22 (3): 499-501.

Sammour, R.; M. A. Hamoud; A. S. Haider and A. Badr (1993): Electrophoretic analysis of the seed proteins of some species in the genus Lotus. Feddes Repertorium, 104 (3): 251-257.

Sheebha, A.; F. Quraiza; M. Thilsath; D. Manohar; S. Sam and R. Bai (2008): Effect of prophylactic antibiotic treatment on the growth and cocoon characteristics of Bombyx mori L. J of Basic and Applied Biology, 2(1): 19-22.

Snedecor, G. and W. Cochran (1981): Statistical Methods. $7^{\text {th }}$ Edition. Iowa State Univ. Press, Ames., Iowa, USA. P.507.

Suparna, M. K.; G. Mallikarjun; S. S. Ingalhalli; V. Shyamkumar and A. A. Hooli (2011): Role of antibacterial proteins in different silkworm strains against flacherie. The Bioscan, 6 (3): 365-369.

Taha, R. H. (2002): Physiological changes of diseased mulberry silkworm, Bombyx mori L. M. Sc. thesis, Ain Shams Univ., Faculty of Science.

Tanada, Y. and H. K. Kaya (1993): Insect pathology. Academic Press, San Diego, P.666.

Venkatesh, K. R. And A. Srivastava (2010): Relevance of antibiotics with reference to sericulture industry. I.J.S.N., 1(2): 97-100.

Yamakawa, M. and H. Tanaka (1999): Immune proteins and their gene expression in the silkworm, Bombyx mori. Developmental and Comparative Immunology, 23: 281-289.

Yeung, P. S. M.; M. E. Sanders; C. L. Kitts; R. Cano and P. S. Tong (2002): Species specific identification of commercial probiotic strains. J. Dairy Sci Association, 85: 1039-1051. 
Hou, Y.; Y. Zou; F. Wang; J. Gong; X. Zhong; Q. Xia and P. Zhao (2010): Comparative analysis of proteome maps of silkworm hemolymph during different developmental stages. Proteome Science, 8:45.

\section{ARABIC SUMMARY}

تأثير المضاد الحيوي (جينتاميسين) على مرض الفلاشيري البكتيري ليرقات دودة القز (بومبكس

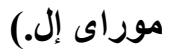

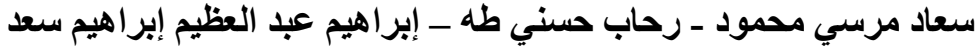

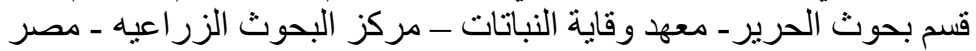

هنالك العديد من العو امل التى تؤثر فى نجاح إنتاج الحرير. ويعتبر مرض الفرض الفلاشيري البكتيري أهمهم

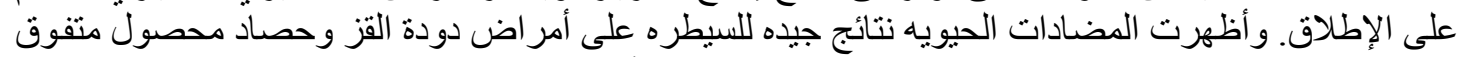

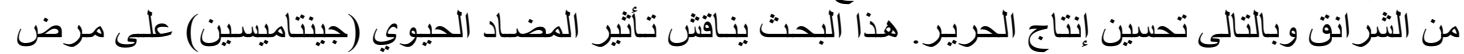

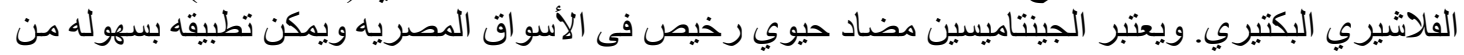

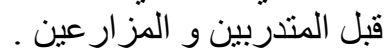

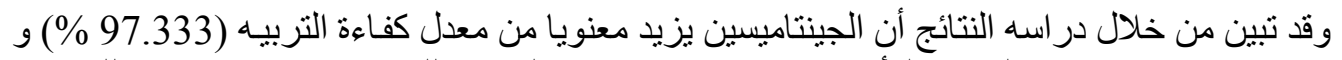

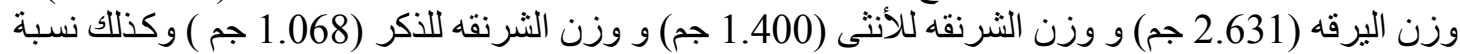
المحتوى الحريري للثرنقه الذكر (22.708 (208).

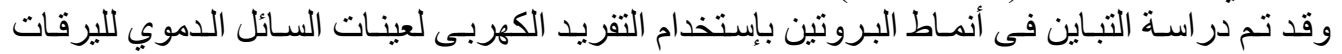

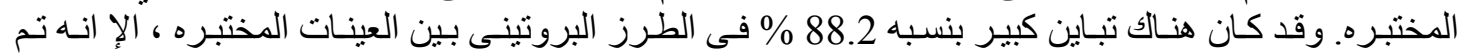

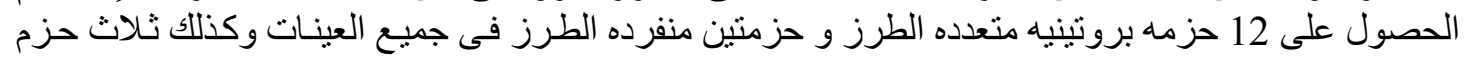
وحيده الطرز . 